\title{
THRA Gene
}

National Cancer Institute

\section{Source}

National Cancer Institute. THRA Gene. NCI Thesaurus. Code C18380.

This gene plays a role in receptor signaling and regulation of transcription. It is involved in thyroid hormone binding. 